\title{
Historical Revisionism in Pakistani Textbooks: A Case Study of Public School Curriculum
}

\author{
Fatima Ebadat Khan \\ Institute of Social and Cultural Studies \\ University of the Punjab, Pakistan.
}

\begin{abstract}
Rising terrorism against religions and ethnic minorities has been an issue for Pakistan in the recent years. This rise in hate crimes and targeted terrorism can be linked with the revisionist history which is being preached through the textbooks of the country. This paper aims to study through a detailed qualitative content analysis how this revisionist history is being created, how facts and language are being manipulated to latently influence the thinking of young school going students to create a feeling if homogeneity within the country in which people that do not become part of the permitted social narrative are looked at upon as outsiders. It was concluded that through distortion, omission of necessary facts and the manipulation of language a systematic narrative is being shaped in the country which creates resentment against religious and ethnic minorities as well as India and the West.
\end{abstract}

Keywords: Revisionist history, curriculum, identity formation

Article Classification: Case Study

\section{Introduction}

The treatment of religious and ethnic minorities is an ever-growing concern in Pakistan. One of the major reasons that the Pakistani society has such a lack of tolerance for diversity of any kind is the education system that is place. Over the years minorities have been eliminated from the curriculum and the standard belief that is ingrained in children's minds from the first day is that Islam is the only religion.

Even the slightest mention of other religions is scrapped from school textbooks. This leads children to be wary of any sort of diversity. Most textbooks contain religious anecdotes of some kind, trying to ensure that the child becomes a practicing Muslim, rather than someone with the analytical and critical thinking of a person who can judge right and wrong on their own.

This article aims to focus on how this skewed curriculum is impacting the thinking of Pakistani youth, how and what sort of ideology is being indoctrinated amongst the masses. The language that is being used will be examined to see how it creates an impact on the mind of the reader to create both negative and positive perceptions of ideas and concepts. This problem has been highlighted by other researchers as well. Hoodhboy and Nayyar (1981) examine the version of history which is being taught at the intermediate and degree levels. They have endeavoured to look at the version of history that is being taught in Pakistan. Their research concluded that Islamic is the ultimate ideology to recast the social fabric of Pakistan and the textbooks make it seem like the reinforcement of Islam is the divine duty of every Pakistani. Moreover, the history changes with the ideology of the ruling elite. In simpler words Pakistan's history and ideology is changed to suit the elite of the country.

Not only were Islamiyat and Pakistan Studies made compulsory subjects during the Zia regime, they are also closely monitored by the Ministry of Education in Islamabad also by Textbook Boards at a provincial level. Specialized committees were made to sift through all books and purge them of any material that they thought was 
unsuitable. An alternate history was constructed by the state which ensured that the people were bound together by ties of Islam and nothing else. (Zaidi, 2011).

During the 1980s a few of the books went as far as to portray Mohammad bin Qasim as the first citizen of Pakistan. The later periods again mention only Muslim rule, with the Hindu and Buddhist rulers either ignored or given only negligible mentions. The same inconsistencies exist in the period of British rule, after citing the Two Nation Theory and highlighting differences between Hindus and Muslims. After the partition, the role of the Armed Forces has been glorified in Pakistani history, important events like the secession of Bangladesh have been made to look like Indian conspiracies. While most textbooks completely ignore the issue several of them also have dedicated chapters in which they talk at length about Mujib Ur Rahman plotting against Pakistan with Hindus (Behuria, Shehzad, 2013).

The problem at present revolves around a marked difference being created between Muslims and other religions. The National Early Childhood Education curriculum lists one of the objectives to nurture a sense of Islamic pride and identity in Pakistanis. While it is not compulsory for minorities to study Islamiyat, they inevitably do so because most of the Pakistan Studies, English and Urdu curricula is based upon Islamiyat as well. The ideology of Pakistan is repeatedly asserted and the basis of the formation of the country is made out to further the cause of Islam. Against Hindus and India there are innumerable passages in books which highlight the differences between Islam and Hinduism.India is identified as the one who instigated hate amongst the West Bengalis and lead to the breaking up of Pakistan (Nayyar, 2005).

Duranni and Dunne (2008) discuss the implications of the skewed education system. Their research finds that the consequences of the present system can be disastrous for the country. People who are different and have diverse identities are at a risk because of a lack of tolerance for otherness in the country.

One of the reasons behind is that that the school curricula being used in the country intensifies homogeneity and, in that effort, creates and 'us' and 'them' narrative, which makes peoples from minorities, the outsiders and creates a level of hate between the two parties. While religious terrorism has always been a problem there has been a steady rise particularly in lynching incidents by mobs in the country.

This research aims to answer how textbooks being used in the country intensify the narrative which promotes otherness between groups in the country. The research questions for this study are as follows

- What is being constructed as the national narrative for society?

- How is this constructed?

- What 'evidence' is used? What is left out?

- What is made problematic and what is not?

- What actions are made desirable for society and what are not?

The existing data gives us a small picture of the problem, in this study the research has tried to fill in some of the gaps which exist in this topic of research. This study talks about issues other than religion which create a divide within the people of the country. Moreover, it also looks at the way certain political ideas for example secularism have been looked down upon in the history books, creating a narrative of hate around them without the children even understanding the concept or what it entails. It also examines the way minorities have treated by way of silence, in the sense that they have no role in Pakistan except for them being in treated fairly and with kindness by the Muslims.

\section{Materials and Methods}

The aim of this study is to analyze how public schools' textbooks perpetuate certain ideas and stereotypes within the minds of students. To gather an in-depth picture of how this takes place, the researcher has chosen the qualitative research model because of its ability to give a richer analysis. In this chapter, we will be examining how the researcher aims to carry out the research process using this model of research effectively to gain a clearer picture of how exactly biases are being perpetuated through history books.

Using the interpretivist approach, this research's primary objective is to discover how students in Pakistan are negatively being affected by the curriculum that is being taught to them. This study further aims to look at how 
school textbooks are promoting biases against religions, cultures, ethnicities as well as political agendas of the people in power thereby planting a negative sentiment right in to the sapling.

This research will thus be conducted using history textbooks being currently used from Punjab, Pakistan from grade six to the grade 12 level and because it aims to unearth how these books are creating negative imagery in the minds of young children who are forced to study these books in school. The researcher will look at books from primary, and secondary sections of government schools of Punjabto get a full picture of the biases which are being internalized into the minds of the youth from the get go.

For this study, the researcher has considered the Pakistan Studies books from public schools in Pakistan, particularly those in use in Punjab. Since education comes under the provincial government, each province has its own textbooks regarding all subjects. Due to the restrictions of time and space for this research, only textbooks from Punjab are being examined against bias and formation of negative attitudes among children. Textbooks are the same in all public schools in the sense that there is a set of textbooks endorsed by textbook boards in each province, and schools can choose which books their students will buy as part of the curriculum. These textbooks have the same knowledge, by and large, because students from all public schools will ultimately undergo the same government exams. This study will be taking a sample of ten textbooks from each level for a thorough content analysis.

The researcher has chosen to move forward with the use of the qualitative content analysis method. Rather than examining the numerical figure by how much textbooks influence school children, the researcher intends to look at how the influence is established in the first place, and what are some of the biases that are being internalized into young children through school education. Hence, the more useful and appropriate tool, for this research, would be qualitative content analysis.

In this research study, we will only be examining secondary data which will be in the form of the sample of public schools' textbooks. The researcher is only examining school textbooks which are prescribed to public schools by the Punjab Textbook Board (PTB). Since there are no individuals involved, there are no issues of having informed consent or issues of hiding the identities of the subjects involved in the study. The data source is the text which thousands of students'study in schools every day of every passing school year. The names of the textbooks and authors will, however, will be named in this paper.

\section{Discussion}

\section{Representation of the Other}

The concept of the 'other' always has an important place in history. The 'other' gives a sense of unity to the people of a nation whether they belong to one race, ethnicity or a geographical area. In the case of Pakistan, the other inevitably takes the form of India since they are portrayed as the prime enemy of the country. In other places it also takes the place of America, as the country is the epitome of western values which are deplorable to the eastern culture of Pakistan. Similarly, before the inception of Pakistan the concept of religion is used to create the other. Hence the Hindus, the Congress and Mahatma Gandhi are all given the treatment of the other in Pakistani textbooks.

Said and Funk (2004) discuss the idea of the narrative of the other. They do this within the context of America and the Middle East and in the broader sense of the West and Islam. The say that dominant narratives from both sides position themselves in the same way; that each civilisation has positioned itself in front of the other. Each civilisation looks to the other only in the sense that the other will define its sense of greatness and increase its value. The same is the case with Pakistan, the geo-political tension that it has faced since its inception has made it put all its adversaries in the them category and the country's sense of greatness and righteousness is defined through them. Lall (2008) says that governments can impose a state curriculum in schools which creates this identity for the young of the nation. In Pakistan this identity is closely linked with the religion, Islam.

\section{Representation of Hindus}

The Hindus have been shown as the enemy in Pakistani books, even in the pre-partition time. The idea seems to be to show that some sort of geographical barrier was necessary between the two religions to exist. The Grade 6 History textbook by the Punjab Textbook board (PTB) quotes, "Delhi Kingdom was mostly populated by 
Hindus which considered Muslims as aliens. They showed no sympathy and interest towards the Muslim rulers and government, so they ever think of their freedom from the Muslims. They always used lame excuse to payment of revenue and taxes. They dared to refuse to pay revenue/tax. "Aside from the glaring issues of grammar and sentence structure in the book, the way the Hindus have been presented is also problematic. The use of words clearly shows them as the enemy to the Muslims who had the audacity to refuse to pay taxes. Their lack of co-operation with the Muslims is shown in a negative light as is their hope to gain freedom form the Muslims. The book ignores the fact that since the Hindus were the native population of the Delhi kingdom it was natural for them to feel resentful of the Muslim Kings who were conquerors and invaders. The language being used in the book is how the seeds of religiosity and enmity are planted in the minds of young children. The concept of an, us and a, them is constructed and thus Hindus and Muslims are put in opposite sides of the spectrum never to be allies always to be enemies. Moreover, the passage from the book squarely places the blames on the shoulders of the Hindus for not trying to coexist; the Muslims are at no fault. It is because of the Hindus that the enmity exists because they are the ones who regard the Muslims as aliens. The book seems to believe that they were wrong in doing so even though the Muslim kings were invaders who had come and conquered Hindu land in the first place.

In the chapter "Socio-Cultural Condition and Transformation of Society During Mughal Period"in the grade 7 PTB History book, there is a section which compares Muslim and Hindu society. One of the passages reads "Muslim society was based on the principle of human equality and brotherhood. These principals were new for Hindu society because they were divided in a brutal caste system which condemned Sudras to the lowest status. Just and equitable system of Islam impressed the Hindus." This quote highlights the way Hindu and Muslim society has continually be juxtaposed in local history books and the Muslim way of life has been claimed as being superior. The fact that the passage says that the principals of equality and brotherhood were new for Hindus shows that they are trying to make the Muslims look superior to them. It also highlights the fact that the Hindus conceded the Muslims as a superior people because of their fair beliefs and actions. The inclusion of such passages is problematic because rather than teaching history in an unbiased manner it promotes the feeling of one party being superior to the other. The passage also implicitly suggests that the Muslims had been kind to the Hindus when they were in power, but this kindness was not returned by the Hindus when they tried to overthrow the Muslims from the seat of power in India, in later years. The representation of the Hindu is thus of one who did not believe in equality and one who did not keep their loyalty and also that they conceded that Islam was a superior religion to Hinduism. Such broad generalisations of other create hate towards them and are obviously problematic in the larger picture of things.

The grade 9 PTB textbooks while discussing the 1971 war with India which discusses the fall of Dhaka has a whole sub heading dedicated to the "Negative Role of Hindu Teachers. "The book states that "...Pakistan's opponent group succeeded in continuing their negative activities...Hindu teachers were in majority in schools and colleges who tarnished the minds of the new generation with Bengali nationalism. They prepared them to rebel against the Ideology of Pakistan. It paved the way for getting separation from West Pakistan." This passage places squarely the blame for the Fall of Dhaka on the shoulders of the Hindu population. The events that lead to the events of the 1971 war and the subsequent separation of Bangladesh are glossed over. The blame is placed on the Hindu population of East Pakistan and none of it is accepted by the politicians of West Pakistan who denied East Pakistan their rightful share in the government. The fact that the passage says that the minds of the new generation were tarnished by Bengali nationalism also highlights that the books believe and want the students to believe that the only positive sort of nationalism is Pakistani nationalism while all other forms are to be condemned. These prejudiced approaches ensure that the minds of students become riddled with prejudice as well since they do not see an objective view of events. Moreover, the fact that Bengali nationalism is frowned upon in this passage also gives it a sense of regionalism in the sense that local history books are insensitive to the sentiments of minorities.

Another quote in the grade 12 PTB textbook for History claims "The Hindu proved prejudiced against the Muslims. The extremist organisations like Sanghtan, Shudhi, Arya Samaj and Hindu Mahasaba endangered the life of the Muslims." This passage again shows that books try to show a negative image of the Hindus in every way. The Hindus in this passage are shown as being hostile to the Muslims and as having a mindless hate towards them which leads them to endanger their lives. The passage perpetuates the hate that two religions seem to have for each other. Moreover, it also labels the Hindus as being mortal enemies for the Muslims, the language being used here makes it seem like the Muslims were the oppressed party by the Hindus. Perpetuating such attitudes in the minds of young children leads them to have a biased and hateful view of a whole community. It also makes it seem like that the Hindus were the ones who had problems with the Muslims whilst the Muslims were free from all the blame. Such absolutes in history are dangerous because they are never true, rather than giving a holistic picture of events these 
textbooks strive to show a narrow minded and tunnel vision of events which portrays the Muslims in a better light than the Hindus.

\section{Representation of the Indian National Congress}

Similarly, the Indian National Congress has repeatedly been vilified in Pakistani textbooks as well. The grade 12 PTB quotes the following passage "It was actually not a national party. It worked for the interests of the Hindus only. The extremists had captured the top positions of the party. 'This passage is not only biased but also untrue in many ways. Firstly, the Congress was a national party; it had members from everywhere in India as well as members from all religions including Islam. The Congress party naturally put more effort towards the interests of the Hindus because the Hindus were in the majority in the subcontinent, it did not have a hidden agenda of maligning and oppressing the Muslims as it is being implied in this paragraph. Moreover, the second half of the statement is not based in fact, because it insists that the extremists had captured all the top positions in the party, because there were many Muslim leaders like Jinnah, Abdul Kalam Azad and Khan Muhammad Abbas Khan. It was not until much later that some Muslim members left and joined the Muslim League. Sweeping statements like the one given in the textbook only promote bias and prejudice.

Another passage in the same book says "The policy of the Indian National Congress created multiple problems for the government and people of Pakistan. It took every step to crush the withering economy of the new state. "Now this quote clearly puts the Congress in the other, in the sense that they are shown as the enemy which wanted to destroy the new born state of Pakistan. It creates hatred in the mind of the reader, portraying Pakistan as the righteous people and the Indians as those who were bent to destroy it even when it was a new state. Moreover, the use of the words crush and withering creates the image of a giant crushing a helpless child, this imagery makes one sympathise with Pakistan and hate India while labelling them as the definitive aggressor. The use of such stereotypical images ensures that the idea of good and evil exists even in textbooks and makes the reader identify with India as bad and Pakistan as good.

\section{Representation of Gandhi}

Gandhi the revered leader of the Indian is also treated with disrespect. Pakistani textbooks often label him as conniving and manipulative, someone who exploited the Muslims for his own means. For example, this passage from the grade 12 PTB textbooks says "Gandhi got a golden chance to exploit the Muslim power for his own purposes." And again, in the same passage "By supporting the Khilafat movement he secured the co-operation of the emotional Muslim for his own purposes. "The language used in the quotes above makes it seem as if Gandhi was deliberately using the Muslims for his own gains. Not only is the information being portrayed in a biased manner in fact it is also untrue because the rest of the book does not present a full picture of the events which would shed light on what happened. The book never mentions the fact that it was because of the outbreak of violence and the deaths of many people that Gandhi called off the non-cooperation movement. Moreover, the language used in the quotes portrays Gandhi as a cunning leader and the Muslims as gullible followers who were misused repeatedly through the course of time. Throughout the book the language used for Gandhi is less than flattering, the words "conniving", "cunning" and "exploited" are always used in relation to him. Moreover, nowhere is Gandhi's politics of non-violence mentioned. Nowhere does the book say that Gandhi to this date is a revered leader because of his non-violence policies. The fact that the book paints a very anti-Muslim sentiment of Gandhi is prejudiced and unbiased. Moreover, the book also ignores many times Gandhi advocated for Hindu-Muslim unity. All his efforts are labelled as exploitative and manipulative which is of course not based in fact.

\section{Representation of the West}

Like the Hindu community the West is portrayed as being anti-Muslim as well. The West is portrayed as an enemy of the Muslims and an ally of the Hindus. In the pre-partition era the British play this part and in the postpartition era the Americans play this part. The West like the Hindus is another omnipresent evil which tries to subjugate the righteous path of the Muslims, sometimes through means of force and at other times trickery and treachery. An example of this is this quote in the grade 9 PTB textbook about the British, "The British dominated by prejudice enmity, dismissed all the Muslims from government jobs especially from the Army and shut the doors of employment to the Muslims." This quote shows how the British are being portrayed as the enemies of the Muslims. They were the ones who alongside the Hindus tried to destroy the Muslims. This quote is written in conjunction to the treatment of the Muslims after the War of Independence. It is misleading because nowhere in the passage related 
to the War of independence does it explain that the British treated the Muslims this way because the war had taken the shape of a predominantly Muslim war. The British would not risk having the Muslims in the army simply because they did not want more war and bloodshed on their hands. Once again, the book does not present a full picture of events, not doing so, twists the events in favour of the Muslims. It shows them as the subjugated underdogs who reigned supreme in the face of all adversary.

Another quote about the British in the grade 12 textbook says "Sir Radcliffe provided a land route to Bharat to move into the valley of Jammu and Kashmir. The Head Works constructed on the land of West Punjab were also handed to Bharat." This quote shows how the common perception in Pakistan is that the Hindus and the British have been allied with each other against them. The language being used implies that the British unjustly favoured the Hindus hence decided to give the contested areas to India. Such language used in history textbooks makes for a biased analysis and creates prejudices inside students' minds because they are repeatedly being taught stereotypes which internalise hate towards certain communities.

The same treatment is given to America; the following quote in the grade 9 textbook tacitly labels the country as a conspirator with India against Pakistan, "America was also involved in these conspiracies. It was proved because when Israel supplied American manufactured arms to India, it did not object." This quote again pits America and India being in league together against Pakistan. Hence through descriptions lie this, the West is always shown to be colluding with the Hindus while Pakistan is side lined, destined to be alone in all wars.

In conclusion it can be deduced that the Pakistani textbooks use many different images of 'the other' to maintain a sense of nationhood. They use the idea of the, us and the, them to have a sort of cohesion in society. According to the analysis every group from the Hindus, to the Congress to the West has been used in such a manner that they are portrayed as adversaries to the Muslims and Pakistan. The effect that this portrayal has is that when Pakistan and the Muslims emerge as victorious according to the books, it cements their status as being the righteous party which has been wronged by the evildoers since centuries to come. This portrayal of purity gives a sense of divinity to whatever Pakistan seeks to accomplish and thus makes all the claims seem more legitimate. This legitimacy gives them a comfortable place in history and gives an assurance to the people that all the actions conducted by their political leaders and their government were the correct actions.

\section{Representationof Muslims}

The 'other', the enemy only exists in books and in history so that the sense of a righteous self is created. Without one of the two the story remains incomplete hence the Hindus and India are created to be hated. The concept of Islam and Pakistan as well as everything related to is glorified in the books. This glorification of self creates a positive image which then metaphorically fights against the evil image of the other which in the case of Pakistan is personified by India. It also unites Pakistan with the rest of the Muslims. This glorification takes place in every aspect linked to religion. Personalities linked to Islam are glorified, the roles of Muslims in important historical events are glorified and Islam relating to nations is also glorified, in the sense that Islamic countries even other than Pakistan have been given more prestige that secular western countries.

The role of religion has been to approve the role of religious and conservative political parties in the political arena; secondly it has been there so the social forces in play in Pakistan are actively against the West and India and thirdly, the unification of the Muslim world. To achieve these political aims, state curriculum has been defined in such a way that history promotes an idea of Islamic citizenship, (Mustafa, 2004).

These ideologies have all come together in local textbooks and have started a trend of glorifying the Muslims. The sense of the Muslim self is celebrated through the celebration of Pakistan, Muslim countries and Muslim personalities.

\section{Representation of Mohammad Bin Qasim}

Social Studies books for the primary grades have little analysis in them. They are mostly a very basic narration of events which have happened. However, even these books start a culture of glorifying the Muslim identity. In the grade 5 PTB Social Studies book, "Muhammad bin Qasim awarded grants to Hindu and Budh leaders and treated them with respect and honour. Many non-Muslims embraced Islam due to good conduct with them. "Similarly, a quote from the grade 4 PTB Social Studies textbooks says "After the victory Muhammad bin 
Qasim treated the non-Muslims well and allowed them to lead their lives according to the teachings of their religion. He awarded grants to Hindu and Budh leaders. Many people converted to Islam due to his good treatment." Now both these quotes glorify the attitude of the Muslims towards the locals. The emphasis in both quotes is upon the good treatment of the non-Muslims at the hand of the Hindus. Looking at this quote alone does not highlight the problem, but if you look at the complete books you will start to see the issues. The first problem is that the quote gives a very positive portrayal of Muslims; this positive portrayal is automatically compared with the very negative view of other religions particularly the Hindus. When both attitudes are compared, it is obvious that the books are trying to show that the Muslims were inherently better than the Hindus. The second issue is the fact that the quote says that many non-Muslims accepted Islam because of the Muslim's good behaviour. This is a very broad generalization plus there are several noted historians like K.K. Aziz who say that this was not the case rather, Islam was accepted by people because of a mixture of fear and other political and economic reasons for example the jizya tax.

\section{Secularism}

Secularism has been a concept which has often been severely denounced in Pakistan. Since it is said that the basis of the creation of the country was having an Islamic identity, secularism is frowned upon as being a product of the western mind. This bias which exists within the political sphere has seeped into history as well and history books are filled with bits and pieces of texts which highlight what an evil secularisation really is. Rather than explaining the concept the history books just look upon in as evil western concept.

The idea of secularism is present mostly in history books of higher education levels like those of the Intermediate level. In all places the word is used it is looked upon as something evil which Islam completely renounces. In the grade 12 PTB textbook it is used in the section which describes the problems that had been faced by the politicians of Pakistan to enforce a set of Islam laws. Here the word secularism is used as being part of a plot to derail Pakistan from its Islamic objective. The passage states "A class of people tried to make the country secular due to their conspiracy; the Islamic laws could not be implemented." The language used here clearly shows that anyone who was in favour of Pakistan becoming a secular nation was part of a scheme to overthrow the Islamic order which was supposed to be the natural order of things. Rather than explaining the word and its meaning and what it truly entails, it is simply portrayed as automatically bad because it hindered the making of an Islamic state. Moreover, the only introduction to secularism the reader gets is part of a plot or scheme through which Islam can be undermined. Hence of course their view of the concept will not remain without partiality.

Secularism is thus given a very negative portrayal in Pakistani history books. It is portrayed as a conspiracy as well the consequence of the mental slavery of the British who had remained in power for so long in the subcontinent. This portrayal of the idea makes it very hard for students and by that extension the people of Pakistan to look at it objectively and to decide whether or not it is good for them or not. Its portrayal as the antithesis of Islam makes it seem like it is ungodly and unholy. The juxtaposition of secularism with the concept of the Islamic state is also problematic. Pitting the two against each other makes it a constant fight between the two; a sort of holy war. Moreover, rather than giving an objective version of the concept it is only mentioned with the barest of facts. Moreover, the portrayal is one of an anti-Islamic ideology which will bring forth the annihilation of religion. Unbiased portrayals make students keep pre-conceived notions of concepts they do not fully understand. Thus, students are prone to having biases against things, ideas and concepts they do not completely comprehend.

\section{Exclusion and Demonization of Minorities}

The issue of minorities is one that has been severely ignored. They have been not only excluded from the national narratives but also from textbooks. Where they have been mentioned they have been talked about in conjunction to the Muslims, being used as the occasional characters which were helped by the Muslims in one way or the other or being left completely silent. Indeed, if one was to believe the Social Studies and Pakistan Studies books Pakistan was a place where non-Muslims could not even set foot in.

Bush and Saltarelli in their research give the definition of the two faces of education and say that it can correspondingly be applied to textbooks (2000). Textbooks can be used to create social cohesion as well as peace on one hand but on the other hand they can be and for most part historically have been used negatively to create mistrust and exaggerate conflict between nations as well as ethnicities and other communities (Naseem and Stober, 2014). 
Naseem (2010) in his research Education and Gendered Citizenship highlights that minorities have been shamelessly omitted from the social as well as the national narrative in Pakistani history textbooks. His analysis of language and social studies textbooks showed that the books only talked about a fixed society where there was no religious diversity. Minorities were simply excluded and were silent and thus of no consequence to the social setting of Pakistan.

\section{Exclusion based on Religion}

The first piece of evidence that we get is from the chapter, 'Ideological Basis of Pakistan' in the grade 9 PTB, Pakistan Studies textbook. The whole chapter talks about how the basis of the formation of formation of Pakistan was so that Islam was strengthened, the basis of the formation of Pakistan is said to be for the supremacy of Islam. To the country is then praised for being a land of pure for the Muslims, amongst other things. In the same chapter under the sub heading 'Fraternity and Brotherhood' it says that Islamic society is based on fraternity and brotherhood and having Islamic society is the reason for the creation of Pakistan. A quote from the Prophet Muhammad (PBUH) is given and it says "Each Muslim is a brother to every other Muslim. He should not commit a breach of trust. He taught to refrain from maliciousness, malignance and enviousness. Therefore, all Muslims should live united. They should help each other." This quote written a chapter which is all about creating a sense of an Islamic identity for Pakistan, highlights how effectively minorities have been excluded from the social fabric of the country. While all Muslims are brothers what is the status of people from other religions. All Muslims are brothers but what is the status of minorities like Hindus, Sikhs, Christians and Parsis? The chapter does not talk about the minorities which are present in the country. They are only mentioned in passing in the book in small sentences in which they are said to be allowed to practice their own religions freely.

Another book for grade 9 Pakistan Studies, says "Pakistan is an ideological state it is based on the specific philosophy of life. Its basis is the religions of Islam. This religion has been in practice for centuries. This is the basis that caused the movement of Pakistan. The ideology of Pakistan means the ideology of Islam. No doubt, the Islamic ideology is the foundation of the ideology of Pakistan." This quote simply shows the reader that the only philosophy behind the creation of Pakistan is that of Islam. Even though the quote is almost four sentences long, it repeats the same message repeatedly. This repetition drives home the message of Pakistan being an Islamic nation. However, it also tacitly shows that there is no space for any religious diversity in the country, if this were not the case the point of Pakistan being an exclusively Islamic nation would not have been driven home the way it has been in the book. This exclusion of other religions naturally creates a sense of misgiving in the minds of minority students who study Pakistan Studies as part of the compulsory curriculum in the country. This homogeneity which is being portrayed hides the diversity of the country and makes this diversity seem as a negative because the foundation of Pakistan is Islam, how can there be any space for other religions.

The grade 12 PTB Pakistan Studies book does the same, in fact it starts doing this from page 1 of the book. The first paragraph of the book talks about once again how Pakistan came into being because of the Islamic ideology. Once again, the paragraph much like the rest of the book excludes minorities. The Islamic ideology is based on the Islamic system and the "Islamic system comprises the fundamental principles of sociology, ethics, politics, religion and economics." While on the surface of it there is nothing wrong with this quote, one still gets a sense of exclusion of minorities in this. This happens because each religious minority has different ideas about religion, ethics, economics and other things that are mentioned in this quote. If only the Islamic principles can be applied in Pakistan, then how will minority rights be safeguarded here? We see minorities face issues in Pakistan because of laws like this. For example, Hindu marriages have gone undocumented by the state for very long because couples had to rely on their wedding photos as proof of being married. There was no proper legal document for them given by the state as proof. A law has been passed by the Sindh and the Punjab Assembly combatting this problem, but it has been done as recently as 2016 and still has not been adopted on the national level.

\section{Exclusion and Demonization of Bengalis}

Bengalis have a very prejudiced representation in Pakistani history books since the Fall of Dhaka in 1971. They have been either excluded completely from the national narrative or at various places in history had the blame pinned on them for what happened. The following quote has been taken from the grade 9 textbook for Pakistan Studies, written by the PTB, the passage illustrates what the writer seems to think was one of the reasons for the separation of Bangladesh from Pakistan, "The arena of politics went to the hands of Suhrawardy, Bhashani and Fazl-ul-Haq who in order to snatch power from each other started supporting Hindu members of the Assembly. 
They used negative tactics to combine people with them. Thus these politicians practiced the policy of make and break to get the chair of power." This use of language in this quote clearly shows that the writer is trying to label these people as power hungry. Not only is this biased and prejudiced but it is also very disrespectful because all three leaders mentioned in the quote had been instrumental in the Pakistan movement, particularly Hussain Shaheed Suharwardy. Moreover, one of the crimes of these politicians as been told in the book is to collude with Hindu politicians. The details of the incident are not given, and the blame is simply pinned on them without any information or real facts.

We see how the books do not give any fair representation to the minorities, they are either not mentioned at all or they are demonised. The general idea which is being created because of the books is that Pakistan is a state with a completely homogenous population with no religious diversity. Such ideas can create adverse impacts on the minds of the students who are taught these books as part of the curricula. People from minorities are not celebrated in these books rather they are not mentioned at all. They are only mentioned in connection to the Muslims, in the sense only in places where the Muslims are being looked at as kind and merciful for letting the minorities practice their religion in peace. An example of this could be this quote takes from the grade 12 book by the PTB which says, "Islam ensures the protection of life, property, honour and traditions of those minorities which live in an Islamic society." While the focus of this quote on the surface is minority rights, the latent meaning of this quote signifies deeper things. Firstly, the emphasis in this sentence remains on Islam because the word has been used twice. Because of this we come to understand that while the minorities may be free to practice their religion they certainly do live in a society which is wholly and solely Islamic. The narrative of the otherness is once again cemented through the language being used. Moreover, the quote also implies that the Islamic society has given these people permission to be free within it; it seems to a privilege rather than a right. Lastly, the minorities are not given any detail, in the sense that they do not have a voice of their own; they are mentioned only in conjecture to the Muslims and Islam. They are important only because they show that the Muslims are glorious and kind to let them worship their own religion in a country where Islam is the driving source behind everything. They do not have a voice which defines them.

\section{Conclusion and Recommendations}

This research aimed to answer the question of how educational tools, particularly school textbooks were contributing to this narrative of otherness. IT consequently found that the national narrative being created by schools focuses on specially doing this. The national identity being constructed emphasises on homogeneity. This creates a oneness between the people who share it but the people who are excluded from it like people of different religions, different political beliefs, different ethnic affiliations. The books with the help of the language create a sense of glorified self; in the sense that anything or anyone who is affiliated with Islam is glorified while all others are demonised. The internalisation of these ideas is hence responsible for creating feelings of hate within the country. These feelings of hate later manifest themselves in the way of terrorism and localised hate crimes as well.

Minorities are not given a fair voice or a fair representation in the history books. Their issues are mostly not spoken about or they are spoken about only in the conjunction to the Muslims. The representation of Pakistan is that of a purely Muslim state. The chapters regarding the ideology of Pakistan are the most important of the books. They talk about how Pakistan is a state for the Muslims. The over emphasis of this makes it seem as if there is no space for anyone else but Muslims in Pakistan. It automatically treats the minorities as if Pakistan is not their country and it makes many Muslims look at them as if they outsiders. This sense of unacceptance being created by the books is problematic because it hampers the integration and cohesion of society. Rather than creating a narrative of social acceptance these books create a narrative of discord and hate.

If the issues with these textbooks are not rectified, Pakistan will have generations of young minds who will be completely brainwashed with no objective sense of history and a false sense of righteousness and supremacy. This will result in creating a polarisation of society of which we already see the seeds being sown for. Pakistan will be torn between the people who align themselves with Islam, against the minorities who will have no option except to leave; a phenomenon which we already see to be on the rise. Moreover, it is necessary that this religious and cultural diversity be preserved rather than edged away.

\section{Abbreviations}

PTB

Punjab Textbook Board 


\section{References}

\section{Primary Sources}

[1]. Ali Shirazi, S., Hussain, M., Hussain Sandhu, A. and Chaudhary, R. (2017). Social Studies Class 4. Lahore: Syed Mobin Mahmood \& Co.

[2]. Ali Shirazi, S., Hussain, M., Hussain Sandhu, A. and Chaudhary, R. (2017). Social Studies Class 5. Lahore: Haq Nawaz Publishers

[3]. Ali, K. (2017). History Class 7. Lahore: Al-Faisal Nashran.

[4]. Choudhary, H., Kawish, M. and Azam, U. (2017). Pakistan Studies Class 9. Lahore: GFH Publishers.

[5]. Chaudhary, H., Khan, S. and Malik, F. (2017). Pakistan Studies Class 12. Lahore: Pakistan Quran Company.

[6]. Hameed, A., Abdul Qadeer, Q. and Khan, S. (2017). History Class 8. 1st ed. Lahore: Punjab Book Depot.

[7]. Muhamad Sharif, M. and Shahzad, T. (2017). History Class 6. 1st ed. Lahore: Kitabistan.

\section{Secondary Sources}

[1]. Behuria, A.K. and Shehzad, M., 2013. Partition of history in textbooks in Pakistan: Implications of selective memory and forgetting. Strategic Analysis, 37(3), pp.353-365.

[2]. Bush, K. and Saltarelli, D., 2000. The two faces of education in ethnic conflict. UNICEF Innocenti Research Centre, Florence.

[3]. Funk, N.C. and Said, A.A., 2004. Islam and the West: Narratives of conflict and conflict transformation. International Journal of Peace Studies, pp.1-28.

[4]. Hoodbhoy, P.A. and Nayyar, A.K. 1985. Rewriting the History of Pakistan. in A. Khan (ed.) Islam, Politics and the State: The Pakistan Experience. London: Zed Books. pp. 164-177.

[5]. Lall, M., 2008. Educate to hate: The use of education in the creation of antagonistic national identities in India and Pakistan. Compare, 38(1), pp.103-119.

[6]. Naseem, M. A. (2009). Construction of Militaristic identities in Pakistani textbooks. In Stephen M. Lyon, and Iain R. Edgar, (Eds.). Shaping a nation: An examination of Education in Pakistan. Karachi: Oxford University Press.

[7]. Durrani, N. and Dunne, M., 2010. Curriculum and national identity: Exploring the links between religion and nation in Pakistan. Journal of Curriculum Studies, 42(2), pp.215-240.

[8]. Nayyar, A.H. and Salim, A. (eds.)(2003). The Subtle Subversion: A report on Curricula and Textbooks in Pakistan. A Civil Society Initiative in Curricula and Textbooks Reform. Sustainable Development Policy Institute, Islamabad.

[9]. Zaidi, A., 2010. A postcolonial sociolinguistics of Punjabi in Pakistan. Journal of postcolonial cultures and societies, 1(3-4), pp.22-55. 